\title{
Money Leaking under the Hood: Problem of Ghost Workers
}

\author{
R. Ramya \\ Head \& Assistant Professor of Economics \\ Sri C. Achutha Menon Government College, Thrissur, Kerala, India \& \\ Research Supervisor, Calicut University, Malappuram, Kerala, India
}

Manuscript ID:

ECO-2021-09023738

Volume: 9

Issue: 2

Month: March

Year: 2021

P-ISSN: 2319-961X

E-ISSN: 2582-0192

Received: 05.01.2021

Accepted: 20.02.2021

Published: 01.03.2021

Citation:

Ramya, R., et al.

"Money Leaking under the Hood: Problem of Ghost Workers." Shanlax International Journal of Economics, vol. 9, no. 2, 2021, pp. 55-58.

DOI:

https://doi.org/10.34293/ economics.v9i2.3738

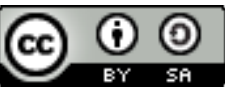

This work is licensed under a Creative Commons Attribution-ShareAlike 4.0 International License

\section{B. Pradeep Kumar}

Head \& Assistant Professor of Economics, Government College, Ambalapuzha, Kerala, India \& Research Supervisor, University of Kerala, Thiruvananthapuram, Kerala, India

https://orcid.org/0000-0003-4232-9640

\section{P. Akshay}

Research Scholar in Economics, Sri C. Achutha Menon Government College, Thrissur, India

\section{Abstract}

Fraud in the institutional setup is like a chronic disease. It leaks scare resources of the organization under the invisible hood. Ghost workers are one of this category that cost both government and corporate institutions. With the positional power in the organization and the collective effort, people are trying to add non-existing workers to the payroll. This is costing a lot of money to the institution all over the world. This investigation would be an attempt to study the nature and existence of the problem of ghost workers.

Keywords: Payroll, Ghost workers, Looting of money, Organization

\section{Introduction}

The inherent tendency of a human being to deceive and corrupt is always a threat to the very existence of the institutional system, irrespective of whether it is a micro or macro setup. Since the human race started its run, it is continuously being hammered by selfish acts of some. Now at this point of our running marathon, corrupters are provided with the contusive platform for sophisticated cheating. The idea of 'Ghost workers' comes at this part. The problems with diverging interest poles of owners and managers are well renounced in economics and management studies. The managers often try to dig deep to get their perks instead of focusing on the prosperity of the organization. This conflict between these units of enterprises is being recognized as 'principalagent problem. Different forms of this problem can be drawn into the frame if the conundrum of 'Ghost workers' is considered. It happens when managers deliberately attempt to earn extra income by creating phony workers. By doing so, the executives would be able to issue payroll for these non-existing workers and keep it under their pockets of mischiefs. The problem of Ghost workers is also known as payroll fraud which affects all companies alike. In many firms, it has been found that the issue of payroll fraud starts with the top managers who are very close to their owners. Payroll fraud is unethical, unprofessional and criminal activity. It not only drains the resources of the organization in which it normally takes place but also spreads the virus corruption and incompetency in the sphere of the business organization, leading to the collapse of the business in the economy. 
The studies of Joe (2002), ACFR (2001), Akeem et al. (2016), Jane (2010), Janet (2007), Murat et al. (2010), etc. made it clear that the existence of ghost workers is undeniable both in government and private sector. As per the study of Thurstone (2012), many countries have a large chunk of ghost workers being paid from a national fund that otherwise would have spent on efficient activities. According to Buckoff (2006), the practices of employment of ghost workers are common in the top level of management. Buckoff believed that deceit often starts from the top and if it is not identified, it would be diffused into other branches of the organization. Jane (2010) supported this theory and stated that large enterprises are often exploited by the management created bogus workers. It is more common in institutions where the central payroll system prevails.

\section{Ghost Workers around the Globe}

The leakage of the institutional funds for ghost workers is a major concern for both government and private companies. For developing countries like Nigeria, Uganda, Honduras, and Papua New Guinea, the existence of ghost workers is a headache for government authorities (Lewis \& Pettersson, 2009). The report of WHO (2001) regarding this problem came up with upsetting data. As per this study, 5\% of teachers in the government sector in Honduras were ghosts, and in Papua New Guinea, it was 15\%. The health sector was not different; in Honduras percentage of bogus workers in the government health department was $8.3 \%$. The data from Nigeria is even worse. The anti-corruption audit in Nigeria on 1.2 million government employees uncovered that $7.6 \%$ of employees are either non-existent or receive a salary on multiple names. It also revealed that there are 23,846 ghost workers saving up to 11.5 million dollars in government payroll in 2016. In another African country, Ghana also the situation is similar. According to the auditor general, in 2007, there were 1,937 non-existing employees saving USD 390,792 from the payroll (Ghana Audit Service, 2007). In 2011 the number of ghost workers in Ghana jumped to 1,800 . For a country being troubled by a growing budgetary deficit, it is a leakage that they can't afford.

\section{Ghost Workers in India}

Many serious scams related to bogus workers attested that India also needs an immediate revaluation of a payroll system. After installing the biometric attendance system, the Municipal Corporation of Delhi (MCD) discovered that they were paying 22,853 'ghost' employees for a long period (Hindustan Times, Nov 26, 2009). They had computed that, because of the identification of ghost employees, they could save 204 crores per annum. Municipal Corporation of Gurugram has also being alleged by the same accusation. A 20-month long investigation done by the civic body reported that at least 300 outsourced MCG workers are ghost workers. It states that there are 1600 accounted workers in MCG, but it pays around 1,950 (Hindustan Times, Aug 31, 2019).

Recently ghost workers scam in Indian railway exposed lapse in critical employee data such as integrated payroll accounting system (IPAS). A preliminary investigation of the railway board concluded that this fraudulent activity cost 1.5 crores to the exchequer during 2016-2017. Board also added that the total loss would be greater if eaccounts and audit reports of all the 16 zones and other railways PSUs are computed. Now railway board initiated attempts to sanitize the data by reviewing the Management Information System (MIS) reports. The railway ministry has announced immediate validation of the employee master data that engenders payroll and establishment claims. These scams exposed that these invisible salary earners can put a hole in the government treasury.

These money looting parasites are always a problem for private enterprises since the industrial revolution. The perfect example of how bad this can be is the Sathyam computer service scam of 2009. It was a corporate scandal worth Rs 7,000-crore INR. Ramalinga Raju has confessed that the company was paying for 53,000 associates, but only 4000 workers existed on the payroll (Business Standard, 2013). Raju also divulged that he has been fudging accounts and conducting Benami transactions for a long time.

\section{How Hard can Ghost Workers Hit?}

Corruption in an organizational setup is always corrosion in the core of its solidity. The mainstay of 
an institution is the mutual trust between every part of its setup. But the self-satisfying goals of some always surpass the idea of collective effort. They try to find every possibility to maximize their utility; most of the time, cheating tools also seem to be feasible for them. They use a variety of methods for enriching their pockets. Payroll fraud is one of the important instruments they have been using. It includes corruptive mechanisms like ghost workers, falsified wages, and commission schemes. According to the Association of central fraud examiners, $29 \%$ of all organizations globally experience payroll fraud. It is happening widely in almost all areas of the economy.

Table 1: Total Payroll Cases in Different Industries

\begin{tabular}{|l|c|c|c|}
\hline \multicolumn{1}{|c|}{ Industry } & $\begin{array}{c}\text { Total } \\
\text { Cases in } \\
\text { Industry }\end{array}$ & $\begin{array}{c}\text { \% of } \\
\text { Payroll } \\
\text { Fraud } \\
\text { in Total } \\
\text { Cases }\end{array}$ & $\begin{array}{c}\text { Total } \\
\text { Payroll } \\
\text { Cases }\end{array}$ \\
\hline $\begin{array}{l}\text { Banking and } \\
\text { Finance }\end{array}$ & 364 & $2 \%$ & 7 \\
\hline $\begin{array}{l}\text { Government } \\
\text { Administration }\end{array}$ & 189 & $17 \%$ & 32 \\
\hline Manufacturing & 177 & $10 \%$ & 18 \\
\hline Health care & 145 & $15 \%$ & 22 \\
\hline Energy & 89 & $6 \%$ & 5 \\
\hline Retail & 89 & $11 \%$ & 10 \\
\hline Insurance & 82 & $13 \%$ & 11 \\
\hline Education & 77 & $13 \%$ & 10 \\
\hline Construction & 64 & $6 \%$ & 4 \\
\hline Transportation & 63 & $11 \%$ & 7 \\
\hline Technology & 62 & $2 \%$ & 1 \\
\hline Telecommunication & 59 & $12 \%$ & 11 \\
\hline Food service & 54 & $22 \%$ & 12 \\
\hline $\begin{array}{l}\text { Service } \\
\text { (Professional) }\end{array}$ & 52 & $8 \%$ & 4 \\
\hline Real estate & $5 \%$ & 4 \\
\hline Source: Asscia & $6 \%$ & \\
\hline
\end{tabular}

Source: Association of Certified Fraud Examiners, Report to the Nation - 2020

This table makes it clear that the cases of payroll fraud are more in government administration. It creates a leakage in the government budget, which is already running on a deficit for all developing countries. The positional powers of executives in the government system provide them an unquestionable authoritative muscle that allows them to manipulate the accounts. A real example of this is above mentioned scams in the Indian railway and MCD. These money-sucking attempts ties huge weights of baggage in the running legs of government. It reduces government expenditure which in turn can ebb social welfare. Efficiency in the provision of public goods also is deteriorating because of this.

Private organizations are similarly exposed to ghost workers and payroll frauds. The authoritative powers of managers and some employees enable them to manipulate payroll and derive extra money from the organization. They may directly create ghost workers or make one with the collaboration of others. Some fictitious persons are using the name of the dead employees for issuing non-existing payroll. In the $47 \%$ of the ghost worker schemes, benefits are concentrated in upper management and accounting/finance functions (Association of certified fraud examiners). This can form a trust bubble throughout the system which would reflect in the smooth functioning of the organization. The profit of the firm would shrink and the competitive power of the institution would be affected. Another undesirable thing related to this is the contribution of unemployment. A lot of people lose opportunities because of the bogus workers on the vacant seats. A higher number of workers in the paper makes it harder to employ new ones in the institution.

\section{Dealing with the Payroll Frauds}

Identification of ghost employees is harder than it seems. But there are some pragmatic methods that can be employed to curb growing payroll frauds. The establishment of a biometric attendance system can be useful. It would detect the attendance of the workers without any paper recording. All workers would have to physically appear for the work to register their attendance. This would eliminate the chance of creating bogus workers to a great extent. Authorities have to conduct regular auditing and monitor the entire payroll system and they have to make sure that there is no communication between management and the auditing entities. 


\section{Conclusion}

Deriving money from ghost employees is common around the globe. Irrespective of the nature of the institution it affects like a virus. It can create holes in the existence of an institutional system and hit the economy hard. There are a lot of crores leaking in the economies because of this issue. Efforts should be made to contain this issue and thereby curb indulged inefficiency. Reviewing of the employee data has to be conducted to find out the intensity of the problem and frame policies to control it.

\section{References}

Amoako-Tuffour, Joe. Ghost Names, Shadow Workers and the Public Sector Wage Bill. An Institute of Economic Affairs Publication, Accra, 2002.

Dini, John F. Employee Fraud: Case Studies of Typical Scams, MPN Business Ownership White Paper, 2011.

Ghana Audit Service, https://www.ghaudit.org

"Ghost Employees." Association of Certified Fraud Examiners, 2001.

Greenlee, Janet, et al. "An Investigation of Fraud in Non-profit Organizations: Occurrences and Deterrents." Nonprofit and Voluntary Sector Quarterly, vol. 36, no. 4, 2007, pp. 676-694.
Honduras: Public Expenditure Management for Poverty Reduction and Fiscal Sustainability, World Bank, 2001.

McCoy, David, et al. "Salaries and Incomes of Health Workers in Sub-Saharan Africa." The Lancet, vol. 371, 2008, pp. 675-681.

Nafiu, Akeem Tunde, et al. "Assessment of the Variations of Ghost Employee Fraud in Nigeria: 2008-2015." European Journal of Business and Management, vol. 8, 2016, pp. 1-10.

Olken, Benjamin, and Rohini Pande. "Lifting the Curtain on Corruption in Developing Countries." VOX, 2012.

Papua New Guinea Public Expenditure and Service Delivery, World Bank, 2004.

Public Expenditure Tracking and Service Delivery Survey - Education and Health in Honduras, Latin America and the Caribbean Regional Office, 2010.

Report of the Auditor General on the Public Accounts of Ghana for the year ended 31st December 2011. Rebulic of Ghana, 2011.

Report to the Nations - 2020 Global Study on Occupational Fraud and Abuse, Association of certified fraud examiners.

Thurston, Anne Catherine. "Trustworthy Records and Open Data." The Journal of Community Informatics, vol. 8, no. 2, 2012.

\section{Authors Details}

Dr. R. Ramya, Head \& Assistant Professor of Economics, Sri C. Achutha Menon Government College, Thrissur, Kerala, India \& Research Supervisor, Calicut University, Malappuram, Kerala, India

Dr. B. Pradeep Kumar, Head \& Assistant Professor of Economics, Government Arts \& Science College, Ambalapuzha, Kerala, India \& Research Supervisor, University of Kerala, Thiruvananthapuram, Kerala, India

Email ID: pradeepgck@gmail.com

P. Akshay, Research Scholar in Economics, Sri C. Achutha Menon Government College, Thrissur, Kerala, India 